\title{
Peace! Mavrone
}

Author(s): Helen Weldon

Source: All Ireland Review, Vol. 3, No. 15 (Jun. 14, 1902), p. 231

Published by: All Ireland Review

Stable URL: http://www.jstor.org/stable/20546104

Accessed: 09-06-2016 09:36 UTC

Your use of the JSTOR archive indicates your acceptance of the Terms \& Conditions of Use, available at

http://about.jstor.org/terms

JSTOR is a not-for-profit service that helps scholars, researchers, and students discover, use, and build upon a wide range of content in a trusted

digital archive. We use information technology and tools to increase productivity and facilitate new forms of scholarship. For more information about JSTOR, please contact support@jstor.org.

All Ireland Review is collaborating with JSTOR to digitize, preserve and extend access to All Ireland Review 
-but for keeping the soil at a certain temperature. Early vegetables pay best, and in order to obtain early produce not only the air but the soil as well must be warmed ; and that is done by putting great quantities of properly mixed manure into the soil; its fermentation heats it. But it is evident that with the present development of industrial skill, the heating of the soil could be obtained more economically and more easily by hot-water pipes. Consequently, the French gardeners begin more and more to make use of portable pipes, or thermosiphons, provisionally established in the cool frames. This new improvement becomes of general use, and we have the authority of Barral's Dictionnaire d'Agriculture to affirm that it gives excellent results.

$$
\text { ( } T \text { o be continued.) }
$$

CUCULAIN OF MURTHEMNE.

Dear Lady Gregory,-Thanks for your noble book. As I was thinking how I might fire up an old volcano, and review the book in the manner it deserves, I got a letter from my old friend and excellent Irish poet, Mr.'Todhunter, promising to do so, whose offer I gladly accepted. I find a great difticulty in reviving old interests. Congratulations on the great success of the book.-S. O'G.

\section{PEACE! MAVRONE.}

What at all's come to me? Sure it's June once more,

White o' the thorn buds for me, 'Tis budding galore.

Spring in me heart there's none,

Ochone! pray for me,

For that thrice cursed morn

Changed all me heart in me.

Changed all me heart in me,

Until now, mavrone,

Lead's in the feet of me,

Me hands are like stone.

Curse the black shot for me

That took him, me own,

Dark, dark morn, weep for me,

Me heart's in the tomb.

What good's now the Peace to me,

For I'm left alone?

E'en Death won't come nigh to me, Now all me joy's gone.

Woman, dear ! ye've no pride in ye : Oh think how he'd mourn

To see the life gone from ye, An' ye cursin' the dawn.

Jewel! hould up the head of ye! An' Heaven itself soon

Will wrap its peace round av ye

Till ye've rest, rest, Mavourn.

Miss Helex Weldon,

Forenaghts, Naas, Co. Kildare.

[DEAR Miss WeLdon,-I am printing your poem, though I almost believe that I ought not to print it. Our work is I think, to put a little life, fire, and force into the poor old country. This is a little too utterly mourn ful. Nevertheless, in it goes. Please, let your nex sound like a trumpet, and wake us up a little.-ED.]

\section{BITS OF IRELAND}

The Heavenly-minded Man.

I was chatting the other day with a farmer in one of the midland counties, who delivered himself on life and conduct to the following effect. "No man, sir, can be happy less than he works hard. Now when a man has done a good honest day's work, and when he has eaten a good supper, and after he has drunk three glasses of beer, he knows that everything is right with him, and then he's a heavenly-minded man."

I never met such a bit of Irish peasant philosophy; and it looks sound too.
SUGGESTIONS HOW TO INCREASE THE NUMBER OF SOUND AGRICULTURAL HOLDINGS AND TO IMPROVE THE LOT OF LABOURERS.

ThE Legislation, from 1881 to that of the present, has given to the many only what it has taken from the few. The promise of increased security as a sort of compensation for losses inflicted has proved to be worse than vain.

The Conservatives resisted Mr. Gladstone's measure in 1881 , in favour of which much might be said, but in 1886 they extended the very same principles to the larger tenants, for which act of treachery to their own supporters nothing can be said, but that it may have been politically expedient. For the smaller yearly tenants were not in a position to obtain reductions of rent in accordance to the fall in prices, without the help of Legislation, but leaseholders and the larger tenants could, by combination, have secured about as much as they were entitled to; in any case, the fact that Legislation has conferred benefits to individuals in proportion to the amount of land held by them is one that may lead to consequences little thought of by the Conservative Government of 1886 .

The man who only holds a little land is naturally disatisfied when comparing his lot with that of his neighbour, whose rent reduction may enable him to live in idleness, whereas he may be practically no better off than before. In some ways the lot of the industrious small tenant with a family is much worse than it was before the Land Legislation. For formerly it was often possible to obtain more land on fairly easy terms, but now the good will of a small holding costs more, as a rule, than the fee-simple and the good will combined used to do before.

It is, therefore, very difficult now for a smaller farmer to keep his children at home, or in Ireland at all.

It is, therefore, perfectly natural that there should be an agitation now in favour of enabling the smaller farms to accuire more land, nor need we wonder that those who have no land should now in many districts be the chosen representatives of the people in District and even County Councils. But where will this constant agitation lead to? If we act on the principle that every man is entitled to so many acres of land, we are bound to provide some corresponding benefit to all those struggling for an existence in towns. In other words, we are bound to destroy nearly all private property, and as credit will be gone long before, it is hard to see how any real improvement in the condition of Ireland can be effected thereby.

There has already been too much of Revolutionary Legislation. Let us by all means keep certain definite ends in view, but let us, at any rate, try to achieve these ends by honest and safe means. Recent Legislation has, I take it,actually retarded the practical solution of the graz ing and the Labour problems-for the hope of taking from one's neighbour coveted land by Act of Parliament, has kept reformers from devising means whereby suitable land could be honestly bought and distributed to the right class of persons, on conditions that would tax the community only to a very slight extent.

No scheme of appropriation can be considered satisfactory that does not at the same time, provide for a suitable method of distribution.

Nothing can be unfairer than the present method of selecting sites for Labourers' Cottages. The labourer, who may be a cripple, or the son of a professional beggar (not imagining cases) selects the most convenient spot on his neighbour's land, and then, if all goes well, and this sugrests an expensive lottery, the land is taken, and perfectly inadequate compensation is promised, but, perhaps, not paid for.

Well, it is, perhaps, good that this is so, for, at any rate in many parts of Ireland, very few cottages have been built. Inagine the state of the country if, instead of taking one statute acre, four or more acres could be taken by these methods.

The Irish are honest, but dishonesty would be perfectly natural in the matter of paying rents in the future for land obtained so dishonestly, and for plots apportioned to future holders on such lines.

(To be continued.)

\section{Smoke MURRAY'S MELLOW MIXTURE

